\title{
EU Law Reform: Cross-Border Civil and Commercial Procedural Law and Cross- Border Insolvency Law
}

\author{
S.F.G. Rammeloo*
}

\section{Introduction}

Business contractors increasingly find themselves involved in a private or commercial law relationship with cross-border elements because of the fact that, e.g. the plaintiff and the defendant may reside in different EU Member States, contract performance is due in a 'foreign' legal order, a court from a 'foreign' country has been designated by the parties, etc. Such cross-border elements may give rise to a dispute culminating into court litigation. The very first question to be answered then is: in which legal order may - or perhaps even must - proceedings be initiated? And, subsequently, how do we deal with the issue that sovereign states tend to be reluctant in recognizing, let alone enforcing, foreign court orders?

The strive for a (European) Single Market yet presupposes the breaking down of (procedural as well as substantive) legal barriers emanating from the crossborder nature of private law relationships, notably business transactions. Ideally speaking, this objective could be attained when, substantively speaking, private and commercial laws would be uniform throughout the entire Market.

But even to date, private and commercial law - inasmuch not harmonized at the EU level, let alone made uniform by EU Regulations or international conventions - largely remains the domain of national law of each individual EU Member State. Consequently, private and commercial law-related disputes showing ties with two or perhaps even more EU Member States inevitably give rise to three questions to be answered: (1) The court of which legal order (i.e. EU Member State or other) must be attributed jurisdiction? (2) Which applicable (national) law applies in court proceedings? And last but certainly not least, (3) how far are court judgments as well as other ex officio documents to be recognized and, even more important to the business world, enforced in other legal orders? Even more, this question comes up in case of businesses declining, i.e. situations involving cross-border insolvency.

Associate Professor EU Private International Law and Comparative Company Law - Faculty of Law, Maastricht University, the Netherlands.
All three questions fall within the ambit of the legal discipline known as Private International Law (PIL). ${ }^{1}$ Like substantive private and commercial law, PIL can be harmonized by EU law as well. This contribution, concentrating on tomorrow's European PIL in notably the area of civil procedural law, highlights the first and the third question from, to start with, the perspective of the upcoming entry into force (10 January 2015) of EU Regulation No. 1215/2012. This instrument provides for a law reform of EU Regulation No. 44/2001 concerning jurisdiction and recognition and enforcement of judgments in civil and commercial matters. A brief kaleidoscope overview of European achievements in the field of PIL is followed by an inquiry into the prevalent changes in this Regulation, notably for business contractors, compared to its predecessor (EU Regulation No. 44/2001). Subsequently, we will focus on another law reform which, however, in this stage is still to be awaited: the Commission's Proposal of December 2012 to amend EU Regulation No. 1346/2000 on Insolvency Proceedings. Finally, overall conclusions are drawn.

\section{The 'Europeanization' of Civil Procedural PIL: Achievements}

How are, from the point of civil procedure, the business and commerce world's interests in cross-border litigation served? In its earliest stage, 'EEC' PIL conceivably focused on 'economic' goals of the Community, i.e. cross-border private and commercial (business) relationships. Consequently, from the outset of the EU law era, Article 220 of the former EC Treaty assigned the six founding EC Member States to enter into negotiations with each other 'as far as necessary' in respect of, inter alia, the "mutual recognition and enforcement of judgments in civil and commercial matters".

Quite daringly (and visionarily), however, the draftsmen preparing the EU legislation even went beyond the assignment taken up in Article 220: not only did they regulate EU PIL on enforcement and recognition of foreign judgments on civil and commercial matters but

1. In Common Law legal orders equally referred to as 'conflict of laws'. 
they also elaborated a conclusive set of jurisdiction rules. This 'double-sided' law concept resulted in a "Brussels Convention on Jurisdiction and Recognition and Enforcement of Judgments in Civil and Commercial Matters". 2 This very first European PIL instrument that entered into force in the year 1973 was furthermore enriched with a protocol attributing uniform interpretative power to the European Court of Justice (CJEU), this power being indispensable to ensure uniformity and utmost legal certainty in advance for notably civil procedural law all over 'Europe'.

Subsequently, further harmonization of PIL was achieved issue wise. Consequently, the compilation of EU Regulations to date looks like a 'patchwork' rather than a conclusive 'Code' on European Private International Law. ${ }^{3}$ In October 2013, however, the EU officially launched the Consilium Civil Lam e-book on European Fudicial Cooperation, which is a compilation of legislative texts and Explanatory Reports. Though 'intended for information purposes only', this compilation may be well considered as a 'semi-codification' tool of European PIL. ${ }^{4}$

In the field of cross-border civil procedural law cum annexis, notably where relevant to the commerce and business world, ${ }^{5}$ a range of $\mathrm{EU}$ law instruments require mentioning in logical order:

- Regulation No. 1346/2000 on insolvency proceedings;

- Regulation No. 44/2001 on jurisdiction and the recognition and enforcement of judgments in civil and commercial matters (replacing the abovementioned Convention 1973);

- Regulation No. 1206/2001 on cooperation between the courts of the Member States in the taking of evidence in civil or commercial matters;

- Regulation No. 805/2004 creating a European enforcement order for uncontested claims;

- Regulation No. 1896/2006 creating a European order for payment procedure;

- Regulation No. 861/2007 on small claims procedures;

- Regulation No. 1393/2007 on the service in the Member States of judicial and extrajudicial documents in civil or commercial matters (service of

2. The legal concept of a 'traité double' or 'double-sided convention' resulted in the adhesive attitude of EU Member States to 'accept' foreign court orders, in the awareness of the fact that foreign courts base their judgments on the very same jurisdiction grounds.

3. Mansel, Thorn, \& Wagner 2013, p. 341.

4. This fully updated document on European PIL containing 911 pages is freely available and downloadable at: <www.european-council.europa. eu/> and <https://bookshop.europa.eu/en/home/s.

5. For a more extended overview on EU Private International Law (i.e. including family law cum annexis), also having regard to the law applicable to cross-border business and commerce, cf. my contribution, Rammeloo 2013, pp. 337-353

6. To be substituted by EU Regulation 1215/2012. Pursuant to Observ. 8 of its Preamble, the 1968 Brussels Convention however continues to apply to the territories of the Member States which fall within the territorial scope of that Convention and which are excluded from this Regulation pursuant to Article 355 of the TFEU. documents) and repealing Council Regulation (EC) No. $1348 / 2000$.

For the purpose of this contribution, both the upcoming 'Recast' of Regulation No. 44/2001 on jurisdiction and the recognition and enforcement of judgments in civil and commercial matters as envisaged by Regulation No. 1215/2012 and Regulation No. 1346/2000 on insolvency proceedings are dealt with below.

\section{EU Regulation 44/2001 on Jurisdiction and the Recognition and Enforcement of Judgments in Civil and Commercial Matters}

\subsection{Scope}

With a view to better understanding of 'Recast' EU Regulation No. $1215 / 2012,{ }^{7}$ it is necessary first to clarify the 'jurisdiction path' to be followed meticulously by courts according to predecessor EU Regulation No. $44 / 2001,{ }^{8}$ as after all the basis of this methodology shall remain unaffected. To that end, first the 'scope' or 'reach' of the Regulation deserves to be described.

Chapter I, Article 1, to start with, defines the substantive scope, i.e. the nature of the disputes falling within the ambit of the Regulation. This instrument applies to 'civil and commercial matters', various topics that may be closely related thereto yet being excluded (disputes having regard to, e.g. capacity, insolvency, arbitration, social security and matrimonial property rights are explicitly excluded).

Chapter II on 'Jurisdiction' commences with Article 2, which provision inter alia defines the formal scope of the Regulation. As a matter of fact, Article 2 fulfils two distinct functions. The first subsection reads: "Subject to this Regulation, persons domiciled in a Member State shall, whatever their nationality, be sued in the courts of that Member State". This provision in the first place thus endorses the traditional actor sequitur forum rei principle (the court of legal order where the defendant resides ${ }^{9}$ has jurisdiction). At the same time, however, Article 2 defines the formal scope (i.e. the geographical and/or personal reach) of the entire 'Brussels I'

7. For doctrinary comments, cf. Knot 2013, p. 145, F.; Cadet 2013, p. 218; Pohl 2013, p. 109; Von Hein 2013, p. 97; Nuyts 2013, p. 63; Nielsen 2013, p. 503; Zilinsky 2013, p. 3.

8. Hereafter this PIL instrument having entered into force on 1 March 2002 shall be referred to as 'Brussels I'.

9. With a view to establishing whether indeed the defendant does reside in the court's territory, for individuals the court seized shall apply its internal laws (Article 59), for legal persons its rules of private international law (Article 60) 
jurisdiction regime ${ }^{10}$ : even when the plaintiff is residing in any non-EU Member State, Member States' (e.g. a US company requesting for payment of goods delivered to a company residing in France) EU Member State courts seized apply the whole 'set' of jurisdiction rules contained in Chapter II. The formal scope of 'Brussels I' is even widened in a specific context, namely, that of 'prorogation': where parties commonly agree on which court shall decide over disputes arising from their civil or commercial relationship ('choice of forum'). Article 23 applies where either of the parties (i.e. regardless whether this is the defendant or the plaintiff) is domiciled in EU territory. The extension of the formal scope of 'Brussels I' in case of choice of forum is explained (and justified) by the fact that the applicability of 'Brussels I' should not depend on who of either party will appear in court as 'defendant'.

\subsection{Jurisdiction}

In everyday practice, neither the legal nor the business world would be satisfied with just one single jurisdiction rule as the one described above in Article 2 (the court of legal order where the defendant resides has jurisdiction). A more sophisticated approach has to be followed, as often a strong and persuasive 'functional' connection exists between proceedings to which this Regulation applies and the territory of certain Member States. As regards the entire 'set' of jurisdiction rules contained in Chapter II, it must be underscored though that these provisions are by no means to be applied in numerical order. Instead, a mandatory following order of jurisdiction rules must be complied with meticulously and mandatorily by lawyers and by courts, Article 2 as a matter of fact being alternatively or even as 'last resort' provision being applicable only.

How does this mandatory following order jurisdiction rules work out in (business) practice? First, the so-called 'exclusive' jurisdiction rules laid down in Article 22 must be checked, as the word 'exclusive' entails the principle that once one of the jurisdiction rules contained in this Regulation provision claims application, no other (Regulation, let alone national) provision whatsoever may apply. The ratio underlying this provision is that certain disputes are deemed to be exclusively linked to the Member State such as the legal order in which territory an immovable property is situated (rights in rem or tenancy of immovable), of the legal order where companies are registered (validity of company constitution, nullity, resolutions, etc.). Likewise, exclusive jurisdiction rules are prescribed for disputes concerning the validity of entries in public registers, validity of patents and trademarks and the enforcement of judgments in the state where enforcement is sought. Repeatedly, however, the CJEU held that as Article 22 has a large impact by setting aside all other Regulation jurisdiction provisions, it has to be interpreted in a restrictive manner.

10. As will be shown below (3.2), Chapter III on recognition and enforcement regime has an even wider formal scope.
Only in case Article 22 does not apply, recourse may (and must) be had to other jurisdiction provisions. Again courts have to adhere to a mandatory following order: first, Sections 3, 4 and 5 providing for protective jurisdiction rules for 'weaker party contracts' (insured individuals, consumers and employees) need to be examined. Subsequently, the quest is for whether or not parties with equal 'market' powers (e.g. a business contract on the sale of goods) agreed on explicit or tacit choice of forum (Articles 23 and 24). In the absence of any such agreement, the search continues: Article 5 contains alternative jurisdiction rules leaving the choice to the plaintiff to start proceedings either in the court where the defendant resides (Article 2) or in one of the courts provided for in Article $5 \mathrm{sub}$ 1-7 (for the business and commerce world, the court notably of the Member State where contractual obligations are or should have been carried out, ${ }^{11}$ or where resulting from tort the harmful event occurred, is of importance).

Alongside this 'catalogue', there are specific Regulation provisions on pending cases, related actions, plurality of defendants, provisional measures, etc.

Civil procedural law requires 'hard and fast rules': full legal certainty and predictability in advance as where court proceedings are to be commenced. For that very reason, numerous interpretative rulings by the Court of Justice of the European Union (CJEU) from 1973 onwards were indispensable. The logical consequence of the need to create full legal certainty in advance is that there is no room whatsoever for the forum non conveniens principle (i.e. courts, though having jurisdiction, denying jurisdiction because allegedly there are contacts with a court of a legal order considered more suited to solve the dispute at stake). ${ }^{12}$

\subsection{Recognition and Enforcement of Foreign Judgments}

It is important to recall once more that the former provision of Article 220 ECT provided a legal basis for the mutual recognition and enforcement of judgments only (jurisdiction matters not being covered) amongst EU Member States of judgments in civil and commercial matters. This challenge has been complied with (as well), namely, by Chapter III of 'Brussels I'.

Why was, at the dawn of the European Union, the emphasis on recognition and enforcement? Cross-border business litigation would be completely useless if not the grounds for non-recognition of foreign judgments would be formulated in an extremely restricted manner. For that reason, Chapter III, notably Sections 1 on recognition and 2 on enforcement, sets clear bounda-

11. The plaintiff may bring action in the court of the defendant (Article 2) or 'in the court for the place of performance of the obligation in question' (Article 5.1, which provision did not undergo any change in Article 7.1 of the Recast). Although this criterion has been autonomously filled in for the sale of movable goods and the rendition of services, over the past decades, a wide range of factual constellations gave rise to questions and a series of preliminary interpretative rulings by the CJEU.

12. Cf., however, below for some exceptions to the forum non conveniens principle. 
ries on non-recognition (allowed for only pursuant to: public policy exception; exclusive or protective jurisdiction were ignored, defaulting appearance of unwarned defendant, judgment irreconcilable with other judgments). By no means is a substantive 'review' by the 'second' court (i.e. the court where recognition and enforcement is sought) allowed for.

Of preeminent importance, to conclude with, is the widened formal scope (the geographical reach) of Chapter III when compared to Chapter II on jurisdiction: any judgment of a Member State court shall be recognized and enforced, even where the defendant residing outside EU territory has been ordered to pay to the plaintiff in the EU taking action pursuant to 'long-armed statutes' (i.e. forum actoris, i.e. jurisdiction in courts where the plaintiff resides) provided for under his national laws, in case the defendant has enforceable properties ( $c f$. movable and immovable goods, bank accounts, etc.) within EU territory. ${ }^{13}$

\section{EU Regulation 1215/2012 ('Recast'): Relevance to Cross-Border Business and Commerce}

\subsection{Scope: Featuring Amendments}

From 10 January 2015 onwards, EU Regulation (EC) No. 44/2001 of 22 December 2000 on jurisdiction and the recognition and enforcement of judgments in civil and commercial matters shall be substituted by EU Regulation $1215 / 2012 .{ }^{14}$ While striving for legal continuity in the area of cross-border civil and commercial procedural law within the European Union, ${ }^{15}$ this instrument yet provides for some important changes. What are the most striking changes for notably business and commerce contractors? ${ }^{16}$

13. EU Member States may however conclude conventions with third nonEU legal orders pursuant to which they shall not enforce judgments against defendants on property within EU territory.

14. EN 20.12.2012 Official Journal of the European Union L 351/13. This Regulation shall apply in all EU Member States except for Denmark. Alongside the Preamble preceding the Regulation, interpretative authority may as well be taken from the Explanatory Report on EU Regulation 1215/2012 (hereafter referred to as: Expl. Rep.). Cf. further the aforementioned Consilium Civil Law e-book on European Judicial Cooperation which compilation of legislative texts and Explanatory Reports, notably Ch. I, F., and, complementary, Ch. II on the Lugano Convention of 30 October 2007 (i.e. the 'paralleled' Convention of 'Brussels I' for EEA legal orders Norway, Iceland, Switzerland and Liechtenstein), both written by F. Pocar.

15. Preamble, Cons. 34. The strive for legal continuity also follows from the wording of Article 80: " $(\mathrm{t})$ his Regulation shall repeal Regulation (EC) No 44/2001. References to the repealed Regulation shall be construed as references to this Regulation and shall be read in accordance with the correlation table set out in Annex III".

16. Other amendments, e.g. those that are related to special protective jurisdiction rules for 'weaker parties' (insured individuals, consumers and employees), will not be dealt with in this contribution.
Of pivotal importance, notably for the business world, is a change of course in view of the relationship between litigation in state courts (notably pursuant to the 'Brussels I' jurisdiction regime) and non-state court dispute resolution, particularly commercial arbitration. This mode of commercial dispute resolution being excluded from the substantive scope of both the predecessor EU Regulation No. 44/2001 and the 2015 Recast, ${ }^{17}$ there was no need to alter the wording of the Regulation (Article 1 subs. 2(d) of both sources). However, from 2015 onwards, courts seized are allowed to take into account that parties in an earlier stage commonly agreed on arbitration rather than litigation in court. This re-orientation was inspired by turmoil in notably the Common Law legal world following the interpretative West Tankers ruling of the CJEU in 2009. ${ }^{18}$ Pursuant to that ruling, a Member State court under the current regime of Regulation No. 44/2001 is not allowed to make an order to restrain a person from commencing or continuing proceedings before the courts of another Member State (an anti-suit injunction) on the ground that such proceedings would be contrary to an arbitration agreement. Under the Recast regime, nothing shall prevent the courts of a Member State, when seized of an action in a matter in respect of which the parties have entered into an arbitration agreement, from referring the parties to arbitration, from staying or dismissing the proceedings or from examining whether the arbitration agreement is null and void, inoperative or incapable of being performed, in accordance with their national law. A ruling given by a court of a Member State as to whether or not an arbitration agreement is null and void, inoperative or incapable of being performed should not be subject to the rules of recognition and enforcement laid down in the Regulation, regardless of whether the court decided on this as a principal issue or as an incidental question. On the other hand, where a court of a Member State, exercising jurisdiction under the Recast Regulation or under national law, has determined that an arbitration agreement is null and void, inoperative or incapable of being performed, this should not preclude that court's judgment on the substance of the matter from being recognized or, as the case may be, enforced in accordance with the Regulation. This should be without prejudice to the competence of the courts of the Member States to decide on the recognition and enforcement of arbitral awards in accordance with the Convention on the Recognition and Enforcement of Foreign Arbitral Awards, in New York on 10 June 1958 ('the 1958 New York Convention'), which takes precedence over Regulation No. 1215/2012. The Regulation should not apply to any action or ancillary proceedings relating to, in particular, the establishment of an arbitral tribunal, the powers of arbitrators, the conduct of an arbitration procedure or any other aspects of such a procedure, nor to any action or judgment con-

17. Van Haersolte-Van Hof 2011, p. 280.

18. CJEU C-185/07 West Tankers. An update of numerous references to this case can be found via <www.conflictoflaws.net> 
cerning the annulment, review, appeal, recognition or enforcement of an arbitral award. ${ }^{19}$ Although arbitration agreements can no longer be ignored without any further notice, legal certainty may be thwarted, as it is for courts of - Civil Law- as well as Common Laworiented - Member States to decide at their own discretion.

\subsection{Jurisdiction: Featuring Amendments}

Notwithstanding the renumbering operation of most Regulation provisions, ${ }^{20}$ both the concept and the mandatory order of jurisdiction provisions as described above (3.2) remain as they were. In view of the exclusive jurisdiction rules, it can be said that the wording of the provision 'on top of the list', Article 24 (i.e. the former Article 22), was copied from its predecessor EU Regulation No. 44/2001.

1. While also leaving aside the special protective-oriented jurisdiction Sections 3, 4 and 5, some other important changes do show a serious impact on the business world. Article 25, to start with, concerning prorogation of jurisdiction, also referred to as 'choice of forum' (the former Article 23) has far-reaching consequences for business transactions on both the European and global scale. The formal scope of Article 25 has been widened considerably under the Recast regime, as regardless of the domicile of either of them, ${ }^{21}$ contract parties may from 2015 onwards agree that a court or the courts of a Member State are to have jurisdiction to settle any disputes which have arisen or which may arise in connection with a particular legal relationship, ${ }^{22}$ that court or those courts shall have jurisdiction. The importance of this extended scope is not only that parties from all over the world may seek justice in 'Europe' for reasons of, inter alia, court 'expertise' or 'neutrality', as may possibilities to enforce a judgment on properties of their counterpart anywhere in the 27 Member States of the 'Brussels I' territory. To effectuate any such choice of forum, they must adhere to formal requirements ${ }^{23}$ as defined in the said Regulation provision (written, evidenced in writing, via electronic means, etc.). Furthermore, an important change is that the EU legislator envisages a certain legal 'symmetry' with the 2005

19. Preamble, Cons. 12

20. This is primarily due to the fact that a provision enshrining autonomous definitions (Article 2) was newly inserted.

21. Under the regime of Article 23 of EU Regulation 44/2001, still either the plaintiff or the defendant must reside in a 'Brussels I' state territory (i.e. all Member States under the exclusion of Denmark).

22. Parties are not allowed to agree on a certain Member State court for 'any of our future legal relationships'.

23. Where a question arises as to whether a choice-of-court agreement in favour of a court or the courts of a Member State is null and void as to its substantive validity, that question should be decided in accordance with the law of the Member State of the court or courts designated in the agreement, including the conflict-of-laws rules of that Member State, Preamble, Cons. 20. In practice this means that any EU Member State court will apply Regulation 593/2008 on the law applicable to contractual obligations to assess which law (as chosen by the parties or, in the absence of such a choice, pursuant to an objective proper law test) governs the contract as regards consent given by parties.
Hague Convention on Choice of Court Agreements. ${ }^{24}$ One of the featuring elements of this Convention which is commonly adhered to in commercial litigation as well as arbitration is now taken up in subsection 5: "An agreement conferring jurisdiction which forms part of a contract shall be treated as an agreement independent of the other terms of the contract. The validity of the agreement conferring jurisdiction cannot be contested solely on the ground that the contract is not valid". The second sentence in a way seems redundant, as the first one already clearly expresses the well-known arbitration law-biased lingua franca commonly referred to as 'separability': in the absence of subsection 5, any choice of forum clause, be it in a separate contract or part of a framework contract, would become perfectly useless, as any (pretense) contestation of the validity of the contract could then be invoked with no other reason than to frustrate the choice of forum clause. As regards the potential 'clash' between the EU 1215/2015 Regulation and the 2005 Hague Convention, it is important to note that once the latter shall enter into force, correspondingly the functional scope of Article 25 of former shall be reduced to litigation between parties both residing in $\mathrm{EU}$ territory.

For yet another reason, the choice of forum agreements may, under the 1215/2012 Recast, become of even greater impact for the global business world. The Preamble also strives to enhance the effectiveness of socalled exclusive choice-of-court agreements in another aspect. With a view to avoid abusive litigation tactics, it is necessary to provide for an exception to the general $l$ is pendens rule in order to deal satisfactorily with a particular situation in which concurrent proceedings may arise. This is the situation where a court not designated in an exclusive choice-of-court agreement has been seized of proceedings and the designated court is seized subsequent$l y$ of proceedings involving the same cause of action and between the same parties. In such a case, the court first seized should, in contrast with CJEU interpretative rulings concerning Regulation No. 44/2001,25 be required to stay its proceedings as soon as the designated court has been seized and until such time as the latter court declares that it has no jurisdiction under the exclusive choice-of-court agreement. This aim of this provision is to ensure that, in such a situation, the court designated by the parties has priority to decide on the validity of the agreement and on the extent to which the agreement applies to the dispute pending before it. The designated court should be able to proceed irrespective of whether

24. Cf. the official website of the Hague Conference on Private International Law, notably on the Convention of 30 May 2005 on Choice of Court Agreements, <www.hcch.net/index_en.php?act=text.display\&tid=134>. "This Convention provides greater certainty to businesses engaging in cross-border activities and therefore creates a legal environment more amenable to international trade and investment". Though not yet in force (ratified by Mexico only), the Convention is expected to be signed by the EU at short notice, as follows from the Proposal for a Council Decision of 30 January 2014, $\operatorname{COM(2014)} 46$ final. Like the EU, the United States signed this Convention.

25. CJEU C-116/02 (Gasser). 
the non-designated court has already decided on the stay of proceedings. ${ }^{26}$

The strive for streamlining the EU Recast Regulation and the 2005 Hague Conference Convention on choice of forum may not be underestimated, as the law on prorogation in cross-border context shall be harmonized considerably, not just at the European level but even on a global scale.

2. The business world, involving European and nonEuropean partners alike, must be prepared to face another major change, like the preceding lines involving cross-border litigation 'beyond' EU borders, however, court prorogation not being agreed on by the litigating parties. Two newly inserted provisions (Articles 33 and 34) authorize Member State courts even to take into account court proceedings commenced in third (i.e. nonEU) Member States. The EU legislator takes the view that the revised Regulation should provide for a flexible mechanism allowing the courts of the Member States to take into account proceedings pending before the courts of third states, considering in particular whether a judgment of a third State will be capable of recognition and enforcement in the Member State concerned ${ }^{27}$ under the law of that Member State and the proper administration of justice. ${ }^{28}$

Article 33 covers full lis pendens situations involving the same parties and the same cause of actions. Where jurisdiction is based on Article 4 (Article 2 of Regulation No. 44/2001, i.e. in accordance with the formal scope principle that the defendant is residing in 'Brussels I' territory) or on Articles 7, 8 or 9 (i.e. business contracting, not involving weaker parties) and proceedings are pending before a court of a third State at the time when a court in a Member State is seized of an action involving the same cause of action and between the same parties as the proceedings in the court of the third State, the court of the Member State may stay the proceedings if: (1) it is expected that the court of the third State will give a judgment capable of recognition and, where applicable, of enforcement in that Member State and (2) the court of the Member State is satisfied that a stay is necessary for the proper administration of justice. The court of the Member State may continue the proceedings at any time if: (1) the proceedings in the court of the third State are themselves stayed or discontinued; (2) it appears to the court of the Member State that the proceedings in the court of the third State are unlikely to be concluded within a reasonable time; or (3) the continuation of the proceedings is required for the proper administration of justice. The court of the Member State shall dismiss the proceedings if the proceedings in

26. Preamble, Cons. 22. This exception should not cover situations where the parties have entered into conflicting exclusive choice-of-court agreements or where a court designated in an exclusive choice-of-court agreement has been seized first. In such cases, the general lis pendens rule of this Regulation should apply.

27. $C f$. as a consequence of a bilateral Convention concluded between individual EU Member States and third countries on mutual recognition of judgments in civil and commercial matters.

28. Preamble, Cons. 23 the court of the third State are concluded and have resulted in a judgment capable of recognition and, where applicable, of enforcement in that Member State. The court of the Member State shall apply this article on the application of one of the parties or, where possible under national law, of its own motion.

The functional scope of Article 34 is to be distinguished from Article 33 in that it envisages actions being 'related' to the action in a Member State's court. Consequently, also the legal parameters differ slightly from those enshrined in Article 33. When a court in a Member State is seized of an action related to the action in the court of the third State, the court of the Member State may stay the proceedings if: (1) it is expedient to hear and determine the related actions together to avoid the risk of irreconcilable judgments resulting from separate proceedings; (2) it is expected that the court of the third State will give a judgment capable of recognition and, where applicable, of enforcement in that Member State; and (3) the court of the Member State is satisfied that a stay is necessary for the proper administration of justice. The court of the Member State may continue the proceedings at any time if: (1) it appears to the court of the Member State that there is no longer a risk of irreconcilable judgments; (2) the proceedings in the court of the third State are themselves stayed or discontinued; (3) it appears to the court of the Member State that the proceedings in the court of the third State are unlikely to be concluded within a reasonable time; or (4) the continuation of the proceedings is required for the proper administration of justice. The court of the Member State may dismiss the proceedings if the proceedings in the court of the third State are concluded and have resulted in a judgment capable of recognition and, where applicable, of enforcement in that Member State. The court of the Member State shall apply this article on the application of one of the parties or, where possible under national law, of its own motion.

Innovating as the legal approach in both Article 33 and Article 34 may seem, proceedings may give rise to hair splitting and cumbersome delays, as they inevitably introduce the risk of a degree of legal uncertainty which more or less can be compared to that of the forum non conveniens doctrine as described above. ${ }^{29}$ Although unlike that doctrine, the court, while applying Article 33 or Article 34, does not deny jurisdiction contra legem, yet the discretionary margins attributed to EU Member State's courts come quite near, as can be demonstrated by earlier preliminary ruling of the CJEU on interrelated actions involving parties (a defendant) residing in a non-EU Member State. In Owusu-Jackson Villa Holidays, ${ }^{30}$ actions were 'related' inasmuch as plaintiff Owusu took action against both a contractor (Jackson) residing in the $\mathrm{UK}$ and, pursuant to an accident in the holiday resort, the alleged tort-feasor, a Jamaican hotel

29. Courts, though having jurisdiction, denying jurisdiction because allegedly there are contacts with a court of a legal order considered more suited to solve the dispute at stake.

30. CJEU C-281/02. 
where the plaintiff suffered physical injuries. The CJEU held that " $(\mathrm{t})$ he (Convention preceding EU Regulation No. 44/2001, SR) precludes a court of a Contracting State from declining the jurisdiction conferred on it by Article 2 of that convention on the ground that a court of a non-Contracting State would be a more appropriate forum for the trial of the action even if the jurisdiction of no other Contracting State is in issue or the proceedings have no connecting factors to any other Contracting State". This preliminary ruling is interesting as the Court in its observations still unconditionally took position against the forum non conveniens doctrine for two combined reasons, namely, legal certainty in advance and protection of $\mathrm{EU}$ citizens in cases like in the main proceedings underlying this judgment.

3. Notably the non-EU business world faces another important change in cross-border commercial proceedings. Under the current regime of 'Brussels I', Article 4 subsection 2 still reads: "(a)s against [a defendant from a non-EU legal order, SR] a person domiciled in a Member State may, whatever his nationality, avail himself in that state of the rules there in force, and in particular those specified in Annex I, in the same way as the nationals of that State". Together with the Annex referred to this provision thus endorses the so-called 'long-armed statute' principle: inasmuch as allowed for under national law of the country where the plaintiff resides (also known as the forum actoris), the plaintiff may initiate court proceedings in its own legal order against a defendant residing outside EU territory. The legal consequences, at least potentially speaking, are far reaching as any payment order from a court in any EU Member States may thus be enforced on the defendant's properties (bank accounts, securities, movable as well as immovable properties, etc.) all over the 'Brussels I' territory. ${ }^{31}$

Pursuant to the $1215 / 2012$ Recast, however, defendants residing in non-EU Member States shall no longer suffer from this species of unfavourable procedural treatment, as this subsection is repealed. Article 5 subsection 2 of the Recast even more explicitly imposes a duty on Member States: "(i)n particular, the rules of national jurisdiction of which the Member States are to notify the Commission pursuant to point (a) of Article 76(1) shall not be applicable as against the persons referred to in paragraph 1 ".

4. On the occasion it may occur to be necessary to 'freeze' real or threatening counterparty actions instantly. To meet circumstances requiring urgency, Article 35 provides that "(a)pplication may be made to the courts of a Member State for such provisional, including protective, measures as may be available under the law of that Member State, even if the courts of another

31. This rule applies except when the Member State where recognition and enforcement is sought concluded a bilateral treatment with the legal order where the defendant applies not to enforce any such judgment (Article 72)
Member State have jurisdiction as to the substance of the matter". ${ }^{32}$

\subsection{Recognition and Enforcement of Foreign Judgments: Featuring Amendments}

As already noticed, the assignment initially imposed on EU Member States was to safeguard the mutual recognition and enforcement of judgments in civil and commercial court proceedings. Like its predecessor, Regulation No. 44/2001, the 2015 Recast would be unavailing if there would be no "mutual trust in the administration of justice in the Union (justifying) the principle that judgments given in a Member State should be recognized in all Member States". Although involving pivotal amendments in the jurisdiction regime as well, the Recast primarily caught lawyer's world's attention for another quite fundamental change in course contained in Chapter III on the recognition and, notably important for business and commerce, the enforcement of judgments from other EU Member States.

1. The Recast regime is revolutionary in that it provides for direct enforcement in the Member State addressed of a judgment given in another Member State. ${ }^{33}$ According to Article 36 subsection 1, a judgment given in a Member State shall be recognized in the other Member States without any special procedure being required. ${ }^{34}$ Even more, as follows from Article 39, "(a) judgment given in a Member State which is enforceable in that Member State ${ }^{35}$ shall be enforceable in the other Member States without any declaration of enforceability being required". Courts, as may other institutions of the recognition and enforcement state, are in other words outplaced. ${ }^{36}$ Pursuant to Article 53, the court of origin

32. The notion of provisional, including protective, measures should include, for example, "protective orders aimed at obtaining information or preserving evidence as referred to in Articles 6 and 7 of Directive 2004/48/EC of the European Parliament and of the Council of 29 April 2004 on the enforcement of intellectual property rights. It should not include measures which are not of a protective nature, such as measures ordering the hearing of a witness. This should be without prejudice to the application of Council Regulation (EC) No 1206/2001 of 28 May 2001 on cooperation between the courts of the Member States in the taking of evidence in civil or commercial matters", Preamble, Cons. 25

33. The very first two Considerations taken up in the Preamble emphasize the importance of a 'free circulation of judgments'. In December 2009, the European Council adopted a new multiannual programme entitled 'The Stockholm Programme - an open and secure Europe serving and protecting citizens', advocating that the process of abolishing all intermediate measures (the exequatur), to be accompanied, however, by a series of safeguards. For the human rights-oriented perspective, cf. Hazelhorst 2014, p. 27.

34. According to the Preamble, Cons. 26, the aim of making cross-border litigation less time-consuming and costly justifies the abolition of the declaration of enforceability prior to enforcement in the Member State addressed. As a result, a judgment given by the courts of a Member State should be treated as if it had been given in the Member State addressed

35. This might not be the case if, for example, the period for appeal has not yet expired.

36. The EU legislator thus relinquished the requirement laid down in Article 38 of the current 'Brussels I' regime: “(a) judgment given in a Member State which is enforceable in that Member State shall be enforceable in another Member State when, on the application of any interested party, it has been declared enforceable there". 
shall, at the request of any interested party, issue the certificate using the form ${ }^{37}$ set out in Annex I. This achievement - direct enforceability, even without a mere 'declaration' in the 'enforcement' Member State - is a substantial breakthrough from the point of view of further facilitating a Single Market.

However, as is stressed by the Preamble, this concept of direct enforcement in the Member State addressed of a judgment given in another Member State without a declaration of enforceability should not jeopardize respect for the rights of the defence. Therefore, the person against whom enforcement is sought should be able to apply for refusal of the recognition or enforcement of a judgment if he considers one of the grounds for refusal of recognition to be present. This should include the ground that he had not had the opportunity to arrange for his defence where the judgment was given in default of appearance ${ }^{38}$ in a civil action linked to criminal proceedings. It should also include the grounds which could be invoked on the basis of an agreement between the Member State addressed and a third State concluded pursuant to Article 59 of the 1968 Brussels Convention. ${ }^{39}$ It may thus not be overlooked that the Recast leads to a legal regime under which the defendant can no longer sit back and await actions but instead should be alert and, on the occasion, must take the initiative.

2. As the aforementioned principle of mutual trust in the administration of justice in the Union may not be thwarted, the recognition and, inasmuch relevant, enforcement of a judgment from another Member State's court should be refused only if one or more of the exhaustive grounds for refusal provided for in the Recast Regulation are present. Alongside 'technical' requirements (documents, transcripts, etc. ${ }^{40}$ that must be complied with mandatorily (Sections 1 and 2 of Chapter III), Section 3 contains an exhaustive list of substantive grounds for 'refusal of recognition and enforcement'. Though taken up in Section 4, Article 52,

37. Inter alia referring to competence of court seized, appeal period being extinct, and evidence of documents handed out to defendant.

38. To that end, the Preamble, Cons. 32, provides that in order to inform the person against whom enforcement is sought of the enforcement of a judgment given in another Member State, the certificate established under this Regulation, if necessary accompanied by the judgment, should be served on that person in reasonable time before the first enforcement measure. In this context, the first enforcement measure should mean the first enforcement measure after such service.

39. Preamble, Cons. 29

40. In case of 'mistakes', the court of the 'enforcement' state needs not to accept certificates 'blindly', as follows from CJEU C-619/10 Trade Agency Ltd./Seramico Investments. That court may thus verify that the information in that certificate is consistent with the evidence and, on the occasion, may refuse to enforce a judgment given in default of appearance which disposes of the substance of the dispute but which does not contain an assessment of the subject matter or the basis of the action and which lacks any argument of its merits, only if it appears to the court, after an overall assessment of the proceedings and in the light of all the relevant circumstances, that judgment is a manifest and disproportionate breach of the defendant's right to a fair trial referred to in the second paragraph of Article 47 of the Charter of Fundamental Rights of the European Union, on account of the impossibility of bringing an appropriate and effective appeal against it. the very point of departure is that "(u)nder no circumstances may a judgment given in a Member State be reviemed as to its substance in the Member State addressed". The premise of mutual trust in the administration of justice in the Union in other words prohibits any authority (i.e. court or other) to exercise a révision au fond on the substantive outcome in the court of the Member State where the judgment was rendered as regards jurisdiction of the court seized or the national law applied, let alone the 'interpretation' of that law.

On meticulously specified grounds, only the recognition and enforcement of a judgment from another Member State's court may be refused. Central provision is Article 54: 1:

(...) (a) if such recognition is manifestly contrary to public policy (ordre public) in the Member State addressed; (b) where the judgment was given in default of appearance, if the defendant was not served with the document which instituted the proceedings or with an equivalent document in sufficient time and in such a way as to enable him to arrange for his defense, unless the defendant failed to commence proceedings to challenge the judgment when it was possible for him to do so; (c) if the judgment is irreconcilable with a judgment given between the same parties in the Member State addressed; (d) if the judgment is irreconcilable with an earlier judgment given in another Member State or in a third State involving the same cause of action and between the same parties, provided that the earlier judgment fulfils the conditions necessary for its recognition in the Member State addressed; or (e) if the judgment conflicts with: (i) Sections 3, 4 or 5 of Chapter II where the policyholder, the insured, a beneficiary of the insurance contract, the injured party, the consumer or the employee was the defendant ${ }^{41}$; or (ii) Section 6 of Chapter II. 2. In its examination of the grounds of jurisdiction referred to in point (e) of paragraph 1, the court to which the application was submitted shall be bound by the findings of fact on which the court of origin based its jurisdiction. 3. Without prejudice to point (e) of paragraph 1 , the jurisdiction of the court of origin may not be reviewed. The test of public policy referred to in point (a) of paragraph 1 may not be applied to the rules relating to jurisdiction. 4. The application for refusal of recognition shall be made in accordance with the procedures provided for in Subsection 2 and, where appropriate, Section 4 .

Where, more particularly, provisional, including protective, measures are ordered by a court having jurisdiction as to the substance of the matter, their free circulation should be ensured under this Regulation. However,

41. The rationale for this refusal ground is the protection of weaker individuals and must further be read in compliance with the requirement that, as regards jurisdiction, if the 'stronger' counterparty commences court proceedings, the summon document must, inasmuch relevant, explicitly inform these weaker parties of their rights to deny a court's jurisdiction. 
provisional, including protective, measures which were ordered by such a court without the defendant being summoned to appear should not be recognized and enforced under this Regulation unless the judgment containing the measure is served on the defendant prior to enforcement. This should not preclude the recognition and enforcement of such measures under national law. Where provisional, including protective, measures are ordered by a court of a Member State not having jurisdiction as to the substance of the matter, the effect of such measures should be confined, under this Regulation, to the territory of that Member State. ${ }^{42}$

3. Another featuring amendment to the regime of EU Regulation No. 44/2001, though not explicitly taken up in any provision, is that a party challenging the enforcement of a judgment given in another Member State should, to the extent possible and in accordance with the legal system of the Member State addressed, be able to invoke, in the same procedure, in addition to the grounds for refusal provided for in this Regulation, the grounds for refusal available under national law and within the time limits laid down in that law. ${ }^{43}$ Understandably, any such national law-biased ground for refusal cannot be of but a residual nature, e.g. 'repairing' obvious mistakes in the wording or, for example, the circumstance that enforcement of the judgment has already been effectuated. Civil procedure has been streamlined in that, contrary to earlier preliminary interpretative rulings of the CJEU, EU law- and national law-based refusal grounds after 10 January 2015 need no longer compulsorily be adjudicated in separate court proceedings. ${ }^{44}$

\section{EU Regulation \\ No. $1346 / 2000$ on Insolvency Proceedings}

\subsection{Scope: Main Features}

A Single Market is likely to give rise to legal complications of its own kind in case of business enterprises facing decline: how to deal with complicated insolvency proceedings having cross-border ramifications? In the absence of, once again, uniform substantive law on crossborder insolvency proceedings, any creditor from any EU Member State aiming at the enforcement of his rights against a debtor may find himself confronted with other creditors from all over the Single Market, or perhaps even third state.

In that respect, the legal premises for insolvency proceedings so far do not even provide for prima facie clarity, as will be seen below (para. 6.1): should they exclusively serve the interest of liquidation of the debtor's properties at the benefit of all creditors, or should

42. Cf. the Preamble, Cons. 33 .

43. Preamble, Cons. 30.

44. CJEU C-139/10 Prism Investments BV. perhaps a more 'societal' approach prevail, to be conceived in the sense that 'rescue operations' and 'prepack' solutions should be covered by an EU law instrument as well? ${ }^{45}$ The answer to this question differs from Member State to Member State. There is, in other words, no common principle underlying the law of all EU Member States. In that respect, it is apt to quote the three general objectives underlying EU Regulation No. 1346/2000 on Insolvency Proceedings ${ }^{46}$ : (1) eliminating the uncertainty resulting from the legislative diversity between Member States by establishing a uniform system of private international law; (2) promoting efficiency, by favouring simple solutions which are easy to apply in practice; and (3) excluding from the Community sphere any differences in treatment associated with the location of the creditor or the source of the credits. $^{47}$

The EIR applies only to insolvency proceedings opened in a Member State against a debtor, independently of his nationality, whose centre of main interests is situated in a Member State. Furthermore, it regulates only the intra-Community effects of such proceedings (i.e. their effects with regard to the law of other Member States), with the sole exception of international jurisdiction, which necessarily functions with regard to third states in order to ensure the universality of the regulatory model adopted. For insolvency proceedings which are not included in the regulation, or for any aspects not covered by it, the private international law of each state applies, with the exception of insurance undertakings, credit institutions or investment undertakings (Article 1(2)). ${ }^{48}$

The Regulation establishes a European framework for cross-border insolvency proceedings. It applies whenever the debtor has assets or creditors in more than one Member State, irrespective of whether he is a natural or legal person. The Insolvency Regulation applies to all Member States with the exception of Denmark. ${ }^{49}$

\subsection{Jurisdiction and Applicable Law (Gleichlauf Principle)}

Main proceedings have to be opened in the Member State where the debtor has its centre of main interests (COMI) and the effects of these proceedings are recognized EU-wide. Secondary proceedings can be opened where the debtor has an establishment; the effects of these proceedings are limited to the assets located in that state.

45. Cf. below (para. 6.1) the proposed amendments

46. Hereafter referred to as EIR. Cf. Ch. 6 of the EU e-book on Civil Law, pp. 332 and et seq., notably the Explanatory Commentary by M. Virgós (further referred to as: Expl. Report EIR (Virgós).

47. Expl. Report EIR (Virgós), p. 335.

48. Two EU Directives have been enacted to date: Directive 2001/17/EC of 19 March 2001 on the reorganization and winding up of insurance undertakings and Directive 2001/24/EC of 4 April 2001 on the reorganization and winding up of credit institutions.

49. Commission Proposal amending Regulation 1346/2000 from 12 December $2012 \operatorname{COM}(2012) 744$ final, including the Explanatory Memorandum (further cited as Expl. Mem. 2012 Proposal EIR). 
In accordance with Article 3(1) EIR, the courts of the Member State within the territory of which the centre of a debtor's main interests is situated shall have jurisdiction to open insolvency proceedings (i.e. the main proceedings), having a 'universal' scope. This means that they aim at encompassing all the debtor's assets and at affecting all creditors, whatever their location, on a worldwide basis and not just on a Community basis. It is important to point out that the EIR does not restrict the international jurisdiction of the courts of the centre of main interests to the European sphere nor does it leave this matter to national law. Of course, the Regulation can only guarantee universal scope mithin the European Community area. Outside the Community, this universal scope depends on the existence of a treaty with the state or states in question and on whether the legal system of such state or states allows it. The centre of main interests is an autonomous concept, i.e. a concept specific to the regulation, with a uniform meaning independent of national law. In order to facilitate its interpretation and application, the regulation (a) provides a definition for the term, offering a uniform concept for all Member States and laying down the bases for realizing it. ${ }^{50}$

The Regulation also contains rules on applicable law and certain rules on the coordination of main and secondary insolvency proceedings. In view of the former category (main proceedings), the very starting point for the EIR is the application of the law of the state of the opening of proceedings. Under Article 4(1), the law applicable to insolvency proceedings and their effects shall be that of the Member State within the territory of which such proceedings are opened, thereafter referred to as the 'state of the opening of proceedings'. This legal concept therefore means that the rules of international jurisdiction have a double-sided role: they determine directly the applicable jurisdiction and indirectly the applicable law. The application of the law of the state of the opening of proceedings (lex fori concursus) as a general rule constitutes one of the general principles of comparative international bankruptcy law and is also commonly referred to as Gleichlauf principle. ${ }^{51}$ As to the precise functional scope of Article 4, the general principle is that it applies to all the phases of the insolvency proceedings: their opening, their conduct and their closure. These phases include the conditions for opening the proceedings; who is entitled to request that opening; the appointment of administrators or receivers, including temporary administrators; the determination of the assets and liabilities; their administration; the admission and ranking of claims; the participation of creditors; the forms of winding up, by reorganization or liquidation and distribution; etc. Article 4(2) of the regulation con-

Cf. recital 13 Preamble: the centre of main interests means the place where the debtor conducts the administration of his interests on a regular basis and is therefore ascertainable by third parties; and (b) establishes a presumption (Article 3(1)) which simplifies the application of the rule - in the case of a company or legal person, the place of the registered office shall be presumed to be the centre of its main interests in the absence of proof to the contrary.

51. Expl. Report EIR (Virgós), p. 340 tains a list of particular matters which are determined by the law of the state of the opening of proceedings. That list is not exhaustive. Its function is to facilitate the interpretation of the basic rule given in Article 4(1) and to resolve any possible problems of characterization to which its application could give rise.

The EIR yet allows for certain exceptions to the law of the EU Member State where proceedings are opened (i.e. the lex fori concursus). Generally speaking, there are two grounds for such exceptions to the application of the lex fori consursus: (1) the protection of the rights acquired in a state other than the state of opening of proceedings against the application of foreign bankruptcy law and (2) on the other hand the need to reduce the complexity of insolvency proceedings. The first reason is of a substantive nature. The application of a single bankruptcy law to all the legal relations of the debtor can be very well understood as a mechanism for promoting collective action. However, the implications, namely, the extension of the effects envisaged under that law to rights or relations set up under a different national law, should be borne in mind. Consequently, there is an inherent tension between establishing a single standard to govern the debtor's insolvency (which justifies the application of the lex fori concursus) and the introduction of an element of unpredictability and of extra cost in the transactions carried out under other legal systems. That is why the exceptions to the application of the lex for concursus can be explained in terms of legal certainty and of protecting expectations in certain matters or areas which are particularly sensitive to interference from different national legislation. The example of Article 9 concerning payment systems and financial markets is paradigmatic. In addition to the substantive argument, there is also a procedural argument. Insolvency proceedings are relatively complex and expensive to administer. Reducing these costs may well favour certain creditors, but can end up benefiting all of them in that the total costs of administering the proceedings are reduced. As we shall see, certain exceptions, or at least certain aspects of these, are justified by the need to facilitate matters. A good example is provided by Article 5 of the regulation on rights in rem. The solution contained there was not adopted because it was the best solution in terms of abstract legislative policy, but because it represented the best balance between satisfying the legislative policy objectives sought and simplicity in applying the rules. Limiting the complexity that international aspects add to the debtor's insolvency and reducing the costs associated with that complexity are part of the regulation's institutional objectives. As pointed out above, the list of exceptions is closed and, under the scope of the regulation, Member States cannot extend it. The regulation lays down special rules for third parties' rights in rem (Article 5), set-off (Article 6), reservation of title (Article 7), contracts relating to immovable property (Article 8), payment systems and financial markets (Article 9), contracts of employment (Article 10), effects on rights subject to registration (Article 11), detrimental acts (Article 13), protection of third-party purchasers 
(Article 14) and effects on lawsuits pending (Article 15). Article 12 on Community patents and trademarks is more of a location rule. ${ }^{52}$

\subsection{Recognition and Enforcement}

The main proceedings under the reign of the EIR extend their effects to all Member States. The EIR thus safeguards the effectiveness of that model by specifying that the decisions adopted under the main proceedings must be recognized and enforced in the other Member States (Article 16). Article 25 addresses the recognition of judgments successively adopted throughout the proceedings (e.g. a decision confirming a composition) or immediately related to them (e.g. a decision annulling an act detrimental to creditors), including preservation measures, and their enforcement. The system of recognition and enforcement followed by the EIR is thus quite similar to the model of recognition established in Regulation (EC) No. 44/2001 on jurisdiction and the recognition and enforcement of judgments in civil and commercial matters. The Insolvency Regulation distinguishes between recognition and enforcement. Whereas recognition is automatic, enforcement is subject to prior control, through a procedure of exequatur or registration. Automatic recognition means that foreign decisions are recognized ipso jure, without any need to resort to preliminary proceedings before having them accepted in the forum of the decision. It is sufficient for the decision to satisfy the conditions laid down in the regulation for that decision to be recognized in all Member States, without any further ado and in its own right. That ensures the effectiveness of the insolvency proceedings, since it saves the costs and delays involved in proceedings where the recognition of a judgment is raised as the principal issue. To date the exequatur or registration procedure is not yet regulated directly; instead, the EIR still pays homage to the concept of the 1968 Brussels Convention, i.e. the predecessor of 'Brussels I' (EU Regulation No. 44/2001). ${ }^{53}$

\section{Commission Proposal Amending EU Regulation No. $1346 / 2000$}

\subsection{Scope}

Adopted in May 2000, the EIR applies since 31 May 2002. Ten years after its entry into force, the Commission has reviewed its operation in practice and considers it necessary to amend the instrument. ${ }^{54}$ In contrast with the 'Brussels I' regime as dealt with above, most measures proposed, however, do not extend to either the law to be applied or to the regime on recognition and enforcement of judgments rendered in insolvency proceedings. ${ }^{55}$ The focus, in other words, is mainly on the EIR's substantive 'scope' and to the accommodation of primary and secondary jurisdiction proceedings to the needs of legal practice.

As regards the Regulation's 'scope', to start with, the Commission observes that it does not cover national procedures which provide for the restructuring of a company at a pre-insolvency stage ("pre- insolvency proceedings") or proceedings which leave the existing management in place ("hybrid proceedings"). Yet have such proceedings recently been introduced in many Member States. ${ }^{56}$ Such proceedings are considered to increase the chances of successful restructuring of businesses. In addition, a number of personal insolvency proceedings are currently outside the Regulation's scope. The proposal therefore extends the scope of the Regulation by revising the definition of insolvency proceedings (Article 1.1) to include hybrid and pre-insolvency proceedings as well as debt discharge proceedings and other insolvency proceedings for natural persons which currently do not fit the definition. Such operations do not involve a liquidator but in which the assets and affairs of the debtor are subject to control or supervision by a court. This amendment would allow proceedings where the debtor remains in possession without a liquidator being appointed to benefit from the EU-wide recognition of the effects of insolvency proceedings which the Regulation brings about. It would also allow more personal insolvency procedures to be covered by the Regulation. In addition, it is proposed to make an express reference to proceedings for the adjustment of debts and to the purpose of rescue in order to include also those proceedings which enable the debtor to find an arrangement with his creditors at a pre-insolvency stage. The amendments would also bring the Regulation more in line with the approach taken by the UNCITRAL Model $\mathrm{Law}^{57}$ on cross-border insolven-

54. Cf. further on this project inter alia EU Parliament document: Directorate General for Internal Policies Policy Department C: Citizens' Rights and Constitutional Affairs Legal Affairs Harmonisation of Insolvency Law at EU Level (2010) available at: <www.europarl.europa.eu/ meetdocs/2009_2014/documents/empl/dv/empl_study_ insolvencyproceedings_/empl_study_insolvencyproceedings_en.pdf $>$ and the so-called Heidelberg-Vienna Report 2012 on the Application of the Insolvency Regulation available at: <http://ec.europa.eu/justice/civil/files/ evaluation_insolvency_en.pdf>. Cf. also, with extended references to sources, Carballo Pińeiro 2014, p. 207.

55. Expl. Mem. 2012 Proposal EIR, p. 6: “this proposal does not envisage changing the existing mechanism according to which the national insolvency procedures covered by the Regulation are listed in Annex $A$ and the Member States decide whether to notify a particular insolvency procedure to be included in that Annex".

56. Expl. Mem. 2012 Proposal EIR, p. 2. For an overview of national preinsolvency and hybrid proceedings, see Section 2 of the Commission report of 12.12.2012 on the evaluation of Council Regulation (EC) No $1346 / 2000$ on insolvency proceedings.

57. <www.uncitral.org/uncitral/en/uncitral_texts/insolvency/1997Model. html> 
cy. ${ }^{58}$ While the extension of the Regulation's scope is important to ensure the efficient conduct of pre-insolvency and hybrid proceedings in a cross-border context, it should not encompass insolvency proceedings which are confidential. There are indeed a number of national re-insolvency proceedings where the debtor enters into negotiations with (certain) creditors in view of reaching an agreement on its refinancing or reorganization, but this information is not made public. These proceedings may entail a moratorium of individual enforcement proceedings or prevent creditors from filing for insolvency proceedings during a certain time period in order to give the debtor some 'breathing space'. While these proceedings may play an important role in some Member States, their contractual and confidential nature would make it difficult to recognize their effects EU-wide because a court or creditor located in another Member State would not know that such proceedings are pending. This does, however, not prevent such a procedure from being subsequently covered by the scope of the Insolvency Regulation as from the moment it becomes public. $^{59}$

\subsection{Jurisdiction: Featuring Amendments}

The Commission observes that there are difficulties in determining which Member State is competent to open (primary, SR) insolvency proceedings. While there is wide support for granting jurisdiction for opening main insolvency proceedings to the Member State where the debtor's COMI is located, there have been difficulties in applying the concept in practice. The Regulation's jurisdiction rules have also been criticized for allowing forum shopping by companies and natural persons through abusive COMI relocation. ${ }^{60}$

1. From the perspective of these primary proceedings, one of the main concerns is the insolvency of company groups: the Regulation does not contain specific rules dealing with the insolvency of a multinational enterprise group although a large number of cross-border insolvencies involve groups of companies. The basic premise of the EIR is that separate proceedings must be opened for each individual member of the group and that these proceedings are entirely independent of each other. The lack of specific provisions for group insolvency often diminishes the prospects of successful restructuring of the group as a whole and may lead to a break-up of the group in its constituting parts. ${ }^{61}$

The proposal retains the concept of the centre of main interest (COMI) because that concept ensures that the case will be handled in a jurisdiction with which the debtor has a genuine connection rather than in the one chosen by the incorporators. The COMI approach is also in line with international developments since it has been chosen as a jurisdictional standard by UNCITRAL in its Model Law on cross-border insolvency. In order to give guidance to legal practitioners in determining COMI, the proposal complements the definition of COMI; it also introduces a provision determining the COMI of natural persons. In addition, a new recital clarifies the circumstances in which the presumption that the COMI of a legal person is located at the place of its registered office can be rebutted; the language of this recital is taken from the Interedil interpretative ruling of the CJEU. ${ }^{62}$ However, the proposal creates a specific legal framework to deal with the insolvency of members of a group of companies while maintaining the entity-by-entity approach which underlies the current Insolvency Regulation. The proposal introduces an obligation to coordinate insolvency proceedings relating to different members of the same group of companies by obliging the liquidators and the courts involved to cooperate with each other in a similar way this is proposed in the context of main and secondary proceedings. Such cooperation could take different forms depending on the circumstances of the case. Liquidators should notably exchange relevant information and cooperate in the elaboration of a rescue or reorganization plan where this is appropriate. The possibility to cooperate by way of protocols is explicitly mentioned in order to acknowledge the practical importance of these instruments and further promote their use. Courts should cooperate, in particular, by exchanging information, coordinating, where appropriate, the appointment of liquidators which can cooperate with each other, and approving protocols put before them by the liquidators. In addition, the proposal gives each liquidator standing in the proceedings concerning another member of the same group. In particular, the liquidator has a right to be heard in these other proceedings, to request a stay of the other proceedings and to propose a reorganization plan in a way which would enable the respective creditors' committee or court to take a decision on it. The liquidator also has the right to attend the meeting of creditors. These procedural tools enable the liquidator which has the biggest interest in the successful restructuring of all companies concerned to officially submit his reorganization plan in the proceedings concerning a group member, even if the liquidator in these proceedings is unwilling to cooperate or is opposed to the plan. ${ }^{63}$

2. Further improvements at least in view of the Commission: the court must examine its jurisdiction $e x$ officio prior to opening insolvency proceedings and to specify in its decision on which grounds it based its jurisdiction. The proposal grants all foreign creditors a right to challenge the opening decision and ensures that these creditors are informed of the opening decision in order to be able to effectively exercise their rights. ${ }^{64}$

3. The proposal clarifies that the courts opening insolvency proceedings also have jurisdiction for actions which derive directly from insolvency proceedings or

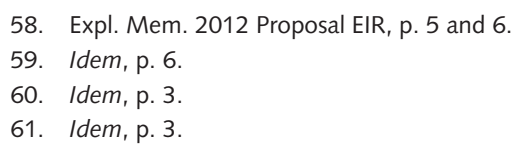

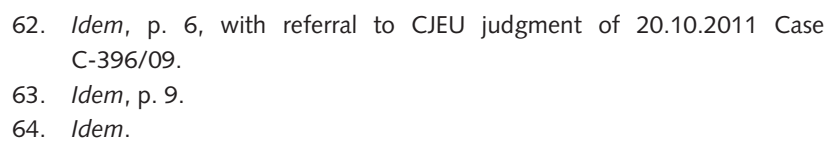


are closely linked with them such as avoidance actions. This amendment codifies the case law of the CJEU in the DekoMarty interpretative judgment. ${ }^{65}$ Where such an action is related to another action against the same defendant which is based on general civil and commercial law, the proposal gives the liquidator the possibility to bring both actions in the courts of the defendant's domicile if these courts are competent pursuant to the above-mentioned EU Regulation No. 44/2001 (as amended). This rule would allow a liquidator to bring, for example, an action for directors' liability based on insolvency law together with an action against that director based on tort law or company law in the same court.

4. Problems have further been identified with respect to secondary proceedings, the opening of which can hamper the efficient administration of the debtor's estate. Any time secondary proceedings in another legal order are commenced, the liquidator in the main proceedings no longer has control over the assets located in the other Member State which makes a sale of the debtor on a going concern basis more difficult. Moreover, secondary proceedings currently have to be winding-up proceedings constituting an obstacle to the successful restructuring of a debtor.

The proposal obliges the court seized with a request to open secondary proceedings to hear the liquidator of the main proceedings prior to taking its decision. This amendment aims to ensure that the court seized with a request for opening secondary proceedings is fully aware of any rescue or reorganization options explored by the liquidator and is able to properly assess the consequences of the opening of secondary proceedings. This obligation is complemented by the right of the liquidator to challenge the decision opening secondary proceedings. ${ }^{66}$

5. The proposal abolishes the current requirement that secondary proceedings have to be winding-up proceedings. Where secondary proceedings are opened, the opening court can choose from the full range of proceedings available under national law including restructuring. This amendment ensures that the opening of secondary proceedings does not automatically thwart the rescue or restructuring of a debtor as a whole. This amendment should be without prejudice to the rules on the recovery of state aid and the jurisprudence of the Court of Justice of the European Union on recovery from insolvent companies. ${ }^{67}$

6. In addition, the proposal improves the coordination of main and secondary proceedings by extending the obligation to cooperate, which currently only applies to the liquidators, to the courts involved in the main and secondary proceedings. Consequently, courts will be obliged to cooperate and communicate with each other; moreover, liquidators will have to cooperate and com13.10.2011 (Commission v. Italy - 'New Interline'). municate with the court in the other Member State involved in the proceedings. Cooperation between courts will improve the coordination of main and secondary proceedings. It can notably be crucial to ensure a successful restructuring, e.g. concerning the approval of a protocol setting out a rescue plan. ${ }^{68}$

Another problem relates to the rules on publicity of insolvency proceedings and the lodging of claims. There is currently no mandatory publication or registration of the decisions in the Member States where a proceeding is opened nor in Member States where there is an establishment. There is also no European Insolvency Register which would permit searches in several national registers. However, the good functioning of cross-border insolvency proceedings relies to a significant extent on the publicity of the relevant decisions relating to an insolvency procedure. Judges need to be aware whether proceedings have already been opened in another Member State; creditors or potential creditors need to be aware that proceedings have commenced. In addition, creditors, particularly small creditors and SMEs, face difficulties and costs in lodging claims under the Insolvency Regulation. ${ }^{69}$

\section{Conclusions}

From its very entry into force in the year 1973, the 'Brussels I' regime on cross-border proceedings in civil and commercial matters has proven to be a cornerstone of the Single (business and commerce) Market. Mutual trust amongst EU Member States presupposes the harmonization of meticulously defined rules on both jurisdiction and recognition and enforcement, the interpretation of these rules even more being safeguarded by preliminary rulings of the CJEU. Pursuant to previous 'recasts', the 'Brussels I' regime has been enriched with notions of, e.g. procedural protection of weaker parties, but also commerce and business benefitted from legal improvements and facilitations.

The Recast regime as enshrined in EU Regulation No. 1215/2012 strives for 'continuity' in cross-border civil and commercial procedural law. Yet this instrument provides for considerable improvements in respect of choice of forum (streamlining of requirements, in line with the 2005 Hague Conference Convention on choice of forum; widened formal; scope). Moreover, business partners from non-EU legal orders need no longer fear 'long-armed statutes' even combined with enforcement of judgments elsewhere in the EU territory as a direct consequence thereof. On the contrary, may EU Member State courts even be inclined to give preference to arbitration agreements setting aside state court dispute resolution, as well as to pending court proceedings in 'third' (i.e. non-EU) Member State courts. In view of jurisdiction and enforcement, the most striking and 
even quite revolutionary amendment is that of 'direct' enforceability of judgments from other EU Member States, urging the defendant to stay alert and, on the occasion, take action rather than awaiting exequatur of the court of the 'enforcement' Member State. Altogether it seems justified to conclude that the Recast regime indeed pays homage to a globalizing (business and commerce) world.

EU Regulation No. 1346/2000 on Insolvency proceedings has proven to be successful. Still, the Commission envisages amendment of this EU instrument. Still, the Commission envisages amendment of this EU instrument, the Proposed amending EIR Regulation being debated. A series of improvements related to primary (ascertainment of COMI) as well as secondary court proceedings may well improve the efficacy of the proposed new EIR.

\section{Bibliography}

F. Cadet, "Main features of the revised Brussels I Regulation", EuZW 2013.

L. Carballo Pińeiro, "Towards the reform of the European Insolvency Regulation: codification rather than modification", NiPR 2014.

M. Hazelhorst, “The ECHR's decision in Provse: guidance for the future of the abolition of exequatur for civil judgments in the European Union. European Court of Human Rights 18 June 2013, decision on admissibility, App. No. 3890/11 (Povse v. Australia)", NiPR 2014.

J.G. Knot, "Herschikking Brussel I", NtER 2013.

H.P. Mansel, K. Thorn, \& R. Wagner, "Europäisches Kollisionsrecht 2012: Voranschreiten des Kodifikationsprozesses - Flickenteppich des Einheitsrechts“, IPRax 2013.

P.A. Nielsen, "The new Brussels I Regulation”, CML Rev. 2013.

A. Nuyts, "Le réfonte du règlement Bruxelles I", Rev.cr.DIP 2013.

M. Pohl, "Die Neufassung der EuGVO - im Spannungsfeld zwischen Vertrauen und Kontrolle", IPRax 2013.

S.F.G. Rammeloo, "European Private International Law: Quo Vadis? A Methodological Journey from Maastricht to Amsterdam, Lisbon and further - Future Challenges", in M. de Visser \& A.P. van der Mei (eds.), The Treaty on the European Union 1993-2013: Reflections from Maastricht, Cambridge, Antwerp, Portland, Intersentia, 2013.

J.J. van Haersolte-Van Hof, "The Commission's proposal to amend the arbitration exception should be embraced", NiPR 2011.

J. von Hein, "Die Neufassung der Europäischen Gerichtsstandsund Vollstreckungsordnung (EuGVO)", RiW 2013.

M. Zilinsky, "De herschikte EEX-Verordening: een overzicht en de gevolgen voor de Nederlandse rechtspraktijk", NiPR 2013. 